\title{
Vitamin D deficiency status in Turkey: A meta-analysis
}

\author{
Medine Alpdemir, $\odot$ Mehmet Fatih Alpdemir
}

Department of Clinical Biochemistry, Balikesir State Hospital, Ministry of Health, Balikesir, Turkey

\begin{abstract}
Objectives: Vitamin D deficiency is a significant public health problem in both developed and developing countries, with a reported worldwide prevalence of $30 \%$ to $80 \%$ among children and adults. The purpose of this study was to examine vitamin D deficiency/insufficiency in Turkey based on a review of the existing research.

Methods: PubMed, DergiPark, The Scientific and Technological Research Council of Turkey (TUBITAK), Google Scholar, Google, and Scopus search engines were queried. The keywords of Turkey, vitamin D, serum 25-hydroxyvitamin D, $25(\mathrm{OH}) \mathrm{D} 3,25(\mathrm{OH})$ vitamin $\mathrm{D}$, deficiency/insufficiency of vitamin $\mathrm{D}$, and prevalence were used in the screening process. The review included prospective and retrospective research studies with healthy individuals of various communities. The Newcastle-Ottawa Quality Assessment Scale was used to assess the risk of bias of the included studies.

Results: A total of 40 studies with a sample size of 111.582 were included in the meta-analysis. The prevalence of vitamin D deficiency was estimated at 63\% (95\% confidence interval [CI]: 58.9-66.6) for the overall population. It was observed that vitamin D deficiency has been reported as $86.6 \%$ (95\% Cl: 70.2-94.6) for infants, $76 \%$ (95\% Cl: 65.2-84.3) for pregnant women, $39.8 \%$ (95\% Cl: 38-41.6) for children, and 63.5\% (95\% Cl: 58.8-67.9) for adults. The prevalence of vitamin D deficiency among women and men was identified as $64.7 \%$ (95\% Cl: $57.5-71.2)$ and $39.5 \%$ (95\% Cl: $31.0-48.7)$, respectively.

Conclusion: The results obtained in this meta-analysis revealed a high rate of vitamin D deficiency in Turkey, which varies from $58.9 \%$ to $66.6 \%$ with $95 \% \mathrm{Cl}$. In particular, neonates, pregnant women, and adult women have a higher risk of vitamin deficiency. The results of this meta-analysis demonstrate that the vitamin D level of the Turkish public should periodically be measured and supplemented as necessary.
\end{abstract}

Keywords: Age, covered clothing, pregnancy, season, sex, Turkish population, vitamin D status

$\mathrm{V}_{\mathrm{t}}$ tamin $\mathrm{D}$ is a steroid hormone that has a major role in bone mineralization through the regulation of calcium and phosphorus metabolism. The main sources of vitamin $D$ are cutaneous synthesis and the ingestion of food, especially fish oil, eggs, and liver [1].

The most common forms of vitamin D absorption are vitamin D2 (ergocalciferol) and vitamin D3 (cholecalciferol). Vitamin D3 is synthesized in the skin through sunlight exposure. This inactive form of vitamin D3 is then metabolized to the prohormone form, 25-hydroxyvitamin (OH)D3, in the liver. The biologically effective form, 1.25(OH)D3, is produced in the kidneys and has a half-life of approximately 2 to 3 weeks, while the circulating half-life of $1.25(\mathrm{OH}) \mathrm{D}$ is only 4 to 6 hours. There- fore, $25(\mathrm{OH}) \mathrm{D} 3$ is generally considered a measure of vitamin $\mathrm{D}$ status [1].

Vitamin D has a substantial function in the maintenance of bone health. A deficiency of vitamin D has been associated with the increased risk of a number of chronic conditions, including cardiovascular disease, diabetes, hypertension, some cancers, autoimmune diseases, neuropsychiatric disorders, metabolic disorders and infectious diseases associated with decreased immunity [2, 3].

The deficiency of vitamin $D$ is a significant problem of public health in both the developed world and developing countries, with a reported prevalence of $30 \%$ to $80 \%$ of children and adults worldwide $[4,5]$. There is not currently enough infor-

Address for correspondence: Medine Alpdemir, MD. Department of Clinical Biochemistry, Balikesir State Hospital, Ministry of Health, Balikesir, Turkey Phone: +90 5054835819 E-mail: bitigic@hotmail.com ORCID: 0000-0003-2625-0246

Accepted Date: May 09, 2019 Available Online Date: May 28, 2019 Available Online Date: October 11, 2019

${ }^{\circ}$ Copyright 2018 by International Journal of Medical Biochemistry - Available online at www.internationalbiochemistry.com 
mation available about the prevalence of vitamin D deficiency in Turkey. The aim of this meta-analysis was to investigate the vitamin $D$ results of various studies of the healthy Turkish population and analyze the reported prevalence of a deficiency of vitamin D.

\section{Materials and Methods}

\section{Search strategy}

This meta-analysis comprised an evaluation and comparison of vitamin D status in the Turkish population of several provinces. The Preferred Reporting Items for Systematic Reviews and Meta-Analyses (PRISMA) guidelines were observed, and the population/intervention/comparison/outcome/study type (PICOS) approach was used, with a focus on the $\mathrm{P}, \mathrm{O}$, and $\mathrm{S}$ elements, due to the descriptive nature of the study. The literature search was conducted in June and July 2017 using an electronic database search. The sources included international (PubMed, Google Scholar, Google, Scopus) and national (DergiPark, The Scientific and Technological Research Council of Turkey [TUBITAK], the Turkish Academic Network and Information Center [ULAKBIM]) databases, which were searched to identify studies published between 2000 and 2017. The search consisted of the following keywords: Turkey, vitamin D, serum 25-hydroxyvitamin D, 25(OH)D3, 25(OH)vitamin D, deficiency/insufficiency of vitamin D, and prevalence. "And" was used to connect all of the keywords. The retrieved studies were screened by reading the titles and abstracts. Publication year, province, study population, study design, sample size, measurement method of vitamin $D$, and outcomes were investigated by the authors. A total of 40 research studies were selected and examined.

\section{Evaluated outcomes and inclusion criteria}

Vitamin D deficiency was defined as $<20 \mathrm{ng} / \mathrm{mL}$, insufficiency was defined as $20-29.9 \mathrm{ng} / \mathrm{mL}$, and sufficiency was described as $>30 \mathrm{ng} / \mathrm{mL}$. The review included studies of healthy participants reflecting all members of the community (neonatal, infant, child, adolescent, adult, elderly, and pregnant women), and studies using radioimmunoassay (RIA), high-performance liquid chromatography (HPLC), and liquid chromatographytandem mass spectrometry (LC-MS/MS) to perform 25-hydroxyvitamin $D$ measurement. The search was restricted to human studies published in English and Turkish.

\section{Exclusion criteria}

Studies related to vitamin $D$ that included diseases of the thyroid gland, kidney, or liver; osteoporosis; stroke; lung emphysema; asthma; cancer; rheumatoid arthritis; multiple sclerosis; HIV; metabolic bone diseases; inflammatory diseases and other chronic diseases were excluded, as well as those that did not include usable data, or were a meta-analysis, review, or case report.

\section{Risk of bias in included studies}

The Newcastle-Ottawa Quality Assessment Scale (NOS) was used to assess the risk of bias in the included studies. The maximum NOS score is 10 points. Studies with a total score of 9-10, 7-8, 5-6 and $<4$ were considered very good, good, satisfactory, and unsatisfactory, respectively.

\section{Summary measures}

Prevalence with a $95 \%$ confidence interval was considered a summary measure of interest.

\section{Data synthesis}

Comprehensive meta-analysis software (Biostat Inc., Englewood, $\mathrm{NJ}$, USA) was used to analyze the data of the selected studies. The prevalence rate was calculated as a summary measure. Heterogeneity was assessed using a chi-square test and the $\mathrm{I}^{2}$ heterogeneity statistic. Forest plots were used to visually assess the effect size of the meta-analysis, the difference in means, and the 95\% confidence interval (Cl) in the selected studies. The groups were classified and analyzed according to the characteristics of neonates, pregnant women, children, adults, and gender.

\section{Results}

During the preliminary search, 767 articles were retrieved and a total of 40 research articles were evaluated. A flow diagram of the phases of the meta-analysis is presented in Figure 1. The total sample size was 111.582 patients. The age range of the study participants was 0 to $>80$ years. The result of a quality assessment according to NOS was between 6 and 9 points. The majority of the studies had a high score $(>8)$, while 11 studies had a point score of $<8$. There was a high level of heterogeneity among the studies $\left(I^{2}=98 \% ; p<0.001\right)$. Thus, a random effects model meta-analysis was performed. In order to determine the frequency of vitamin $D$ deficiency in the Turkish population, a total of 23 retrospective studies and 17 prospective cross-sectional studies were included: 17 studies of neonates, infants, children and adolescents; 12 studies of pregnant women; 9 studies of adults; 3 studies of the elderly; 7 studies examining clothing style; and 13 studies analyzing the effect of age, sex, and season. The basic characteristics of the included studies according to location are provided in Tables 1-3.

The prevalence rate of vitamin $D$ deficiency was determined to be $63 \%$ (95\% Cl: 58.9-66.6) for the overall population. The prevalence of vitamin $D$ deficiency for neonates, pregnant women, children, and adults was $86.6 \%$ (95\% Cl: 70.2-94.6), 76\% (95\% Cl: 65.2-84.3), 39.8\% (95\% Cl: 22.6- 57.5), and 63.5\% (95\% Cl: 58.8-67.9), respectively. Female and male residents had a $64.7 \%$ (95\% Cl: $57.5-71.2)$ and $39.5 \%$ (95\% Cl: 31.0-48.7) prevalence of vitamin D deficiency, respectively. In neonates, the lowest rate reported was $53.3 \%$ (95\% Cl: 46.6-66.8) in a study performed in Istanbul by Ozdemir et al. [7], and the highest rate was $93 \%$ (95\% Cl: 89.2-95.5) in a study conducted in Izmir by Halicioglu et al. [8]. In children, the lowest rate was 


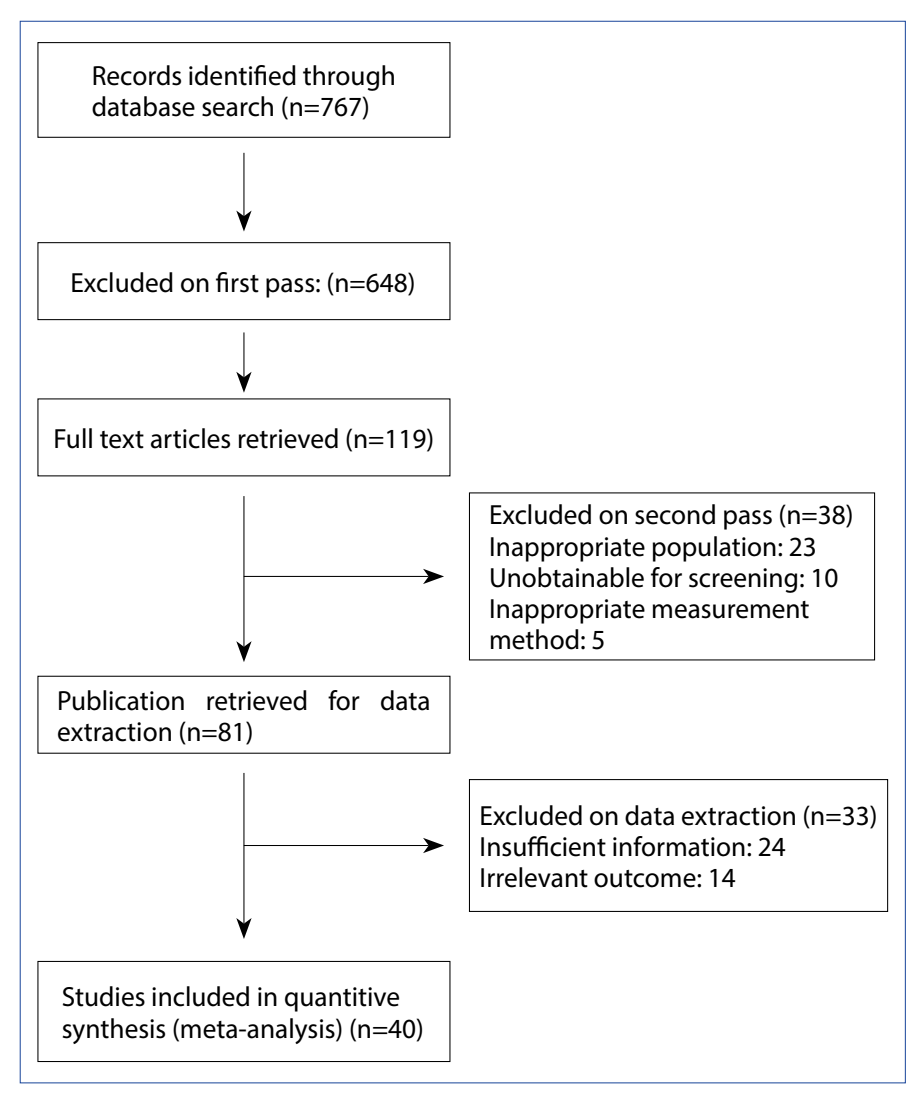

Figure 1. Flow diagram of the phases of the meta-analysis.

determined to be $8 \%$ (95\% Cl: 6-10) in a study in Ankara investigated by Akman et al. [19], and the highest rate was reported as $82 \%$ (95\% Cl: 79.1-84.6) in a study in Trabzon conducted by Karaguzel et al. [15] In adults, the lowest rate determined was $34 \%$, observed in a study in İstanbul performed by Buyukuslu et al. [29], and the highest rate was $91 \%$, reported by Bozkurt et al. in a study carried out in Ankara (Fig. 2-7).

\section{Neonates and infants}

Tables 1 and 2 illustrate the results of studies including neonates and infants. In the study performed by Arica et al. [6] in the Van region, 115 children of between 0 and 36 months of age were included between July and September. The mean length of breastfeeding was $9.4 \pm 6.6$ months. There was no significant difference in the 25(OH)D3 level according to sex. The mean vitamin $D$ deficiency $(<20 \mathrm{ng} / \mathrm{mL})$ of the participants was $49 \%$. In all, $32 \%$ were taking a vitamin D supplement, and $80.2 \%$ of those receiving a supplement of 4 vitamin D drops or more had an $25(\mathrm{OH}) \mathrm{D} 3$ level $>40 \mathrm{ng} / \mathrm{mL}$. The mean length of daily sun exposure for infants with a $25(\mathrm{OH})$ D3 level of $>40$ $\mathrm{ng} / \mathrm{mL}$ was determined to be 56.48 minutes. Ozdemir et al. [7] included 90 neonates in their study. The mean 25(OH)D3 level was $13.16 \pm 7.16 \mathrm{ng} / \mathrm{mL}$ for all of the newborns. They found that $53.3 \%$ of 1 -week-old infants in their study had vitamin $D$ deficiency. In the study conducted by Halicioglu et al. [8], the mean concentration of $25(\mathrm{OH}) \mathrm{D} 3$ in infants was determined to be $11.5 \pm 6.8 \mathrm{ng} / \mathrm{mL}$. In another study conducted in Ankara in $2010,58.6 \%$ of infants were found to have vitamin D deficiency ( $\leq 20 \mathrm{ng} / \mathrm{mL}$ ) [9]. In another study performed by Ergur et al. [10], $18.6 \%$ of the mothers and $2.9 \%$ of the neonates had normal vitamin D levels. Yildiz et al. [11] found a mean $25(\mathrm{OH})$ D3 level of $11.5 \pm 5.9 \mathrm{ng} / \mathrm{mL}$ and $10.9 \pm 5.9 \mathrm{ng} / \mathrm{mL}$ for mothers and infants, respectively, during winter months. Gülez et al. [12] found a prevalence of vitamin D deficiency of $31 \%$ in a study of 100 infants in Izmir aged 0-24 months. However, 63\% of this patient group was receiving a vitamin $D$ supplement and $52 \%$ of them were exposed to sunlight regularly.

In these studies, the rate of vitamin D deficiency prevalence among infants in Turkey ranged from $2.9 \%$ to $58.9 \%$. Even though Turkey has high levels of sun exposure, vitamin D deficiency remains an important problem, particularly among pregnant women, infants, and adolescents [13].

\section{Children and adolescents}

The results of the studies investigating children are shown in Table 1. In a study performed on adolescent girls in Turkey, Hatun et al. [14] found a rate of deficiency of vitamin D of

\begin{tabular}{|c|c|c|c|c|c|c|c|c|c|c|}
\hline \multirow[t]{2}{*}{ Study name } & \multirow[t]{2}{*}{ Subgroup within study } & \multicolumn{5}{|c|}{ Statistics for each study } & \multicolumn{4}{|c|}{ Event rate and $95 \% \mathrm{Cl}$} \\
\hline & & $\begin{array}{l}\text { Event } \\
\text { rate }\end{array}$ & $\begin{array}{l}\text { Lower } \\
\text { limit }\end{array}$ & $\begin{array}{l}\text { Upper } \\
\text { limit }\end{array}$ & Z-Value & p-Value & & & & \\
\hline Ozdemir et al. (7) & Neonates & 0.570 & 0.466 & 0.668 & 1.324 & 0.186 & & & & \\
\hline Halicioglu et al. (8) & Neonates & 0.930 & 0.892 & 0.955 & 10.601 & 0.000 & & & & \\
\hline Gur et al. (9) & Neonates & 0.590 & 0.491 & 0.682 & 1.781 & 0.075 & & & & \\
\hline Ergur et al. (10) & Neonates & 0.970 & 0.891 & 0.992 & 4.961 & 0.000 & & & & \\
\hline Yildiz et al. (11) & Neonates & 0.900 & 0.856 & 0.932 & 10.422 & 0.000 & & & & \\
\hline \multirow[t]{3}{*}{ Alp et al. (34) } & Neonates & 0.940 & 0.862 & 0.975 & 5.881 & 0.000 & & & & \\
\hline & & 0.866 & 0.702 & 0.946 & 3.632 & 0.000 & & & & \\
\hline & & & & & & & -1.00 & -0.50 & 0.00 & 0.50 \\
\hline
\end{tabular}

Figure 2. Forest plot of prevalence of vitamin D deficiency in neonates. 


\begin{tabular}{|c|c|c|c|c|c|c|c|c|c|c|c|}
\hline \multirow[t]{2}{*}{$\underline{\text { Study name }}$} & \multirow[t]{2}{*}{ Subgroup within study } & \multicolumn{5}{|c|}{ Statistics for each study } & \multicolumn{5}{|c|}{ Event rate and $95 \% \mathrm{Cl}$} \\
\hline & & $\begin{array}{c}\text { Event } \\
\text { rate }\end{array}$ & $\begin{array}{l}\text { Lower } \\
\text { limit }\end{array}$ & $\begin{array}{l}\text { Upper } \\
\text { limit }\end{array}$ & Z-Value & $\mathrm{p}$-Value & & & & & \\
\hline Ozdemir et al. (7) & Pregnant & 0.500 & 0.402 & 0.598 & 0.000 & 1.000 & & & & & \\
\hline Halicioglu et al. (8) & Pregnant & 0.900 & 0.857 & 0.931 & 10.588 & 0.000 & & & & & \\
\hline $\begin{array}{l}\text { Gur et al. (9) } \\
\text { Ergur et al. (10) }\end{array}$ & $\begin{array}{l}\text { Pregnant } \\
\text { Mothers }\end{array}$ & $\begin{array}{l}0.620 \\
0.810\end{array}$ & $\begin{array}{l}0.521 \\
0.701\end{array}$ & $\begin{array}{l}0.710 \\
0.886\end{array}$ & $\begin{array}{l}2.364 \\
4.759\end{array}$ & $\begin{array}{l}0.018 \\
0.000\end{array}$ & & & & & \\
\hline Yildiz et al. (11) & Pregnant & 0.850 & 0.800 & 0.889 & 9.793 & 0.000 & & & & & \\
\hline Gulez et al. (12) & Mothers & 0.820 & 0.732 & 0.884 & 5.826 & 0.000 & & & & & \\
\hline Pehlivan et al. (32) & Mothers & 0.790 & 0.686 & 0.866 & 4.766 & 0.000 & & & & & \\
\hline Parildar et al. (33) & Pregnant & 0.360 & 0.262 & 0.472 & -2.439 & 0.015 & & & & & \\
\hline Alp et al. (34) & Mothers & 0.950 & 0.875 & 0.981 & 5.776 & 0.000 & & & & & \\
\hline Gur et al. (35) & Pregnant & 0.760 & 0.703 & 0.809 & 7.706 & 0.000 & & & & & \\
\hline Erol et al. (38) & Pregnant & 0.700 & 0.550 & 0.816 & 2.576 & 0.010 & & & & & \\
\hline \multirow[t]{2}{*}{ Random } & & 0.760 & 0.652 & 0.843 & 4.305 & 0.000 & & & & & \\
\hline & & & & & & & -1.00 & -0.50 & 0.00 & 0.50 & 1.00 \\
\hline
\end{tabular}

Figure 3. Forest plot of prevalence of vitamin $D$ deficiency in pregnant/mother.

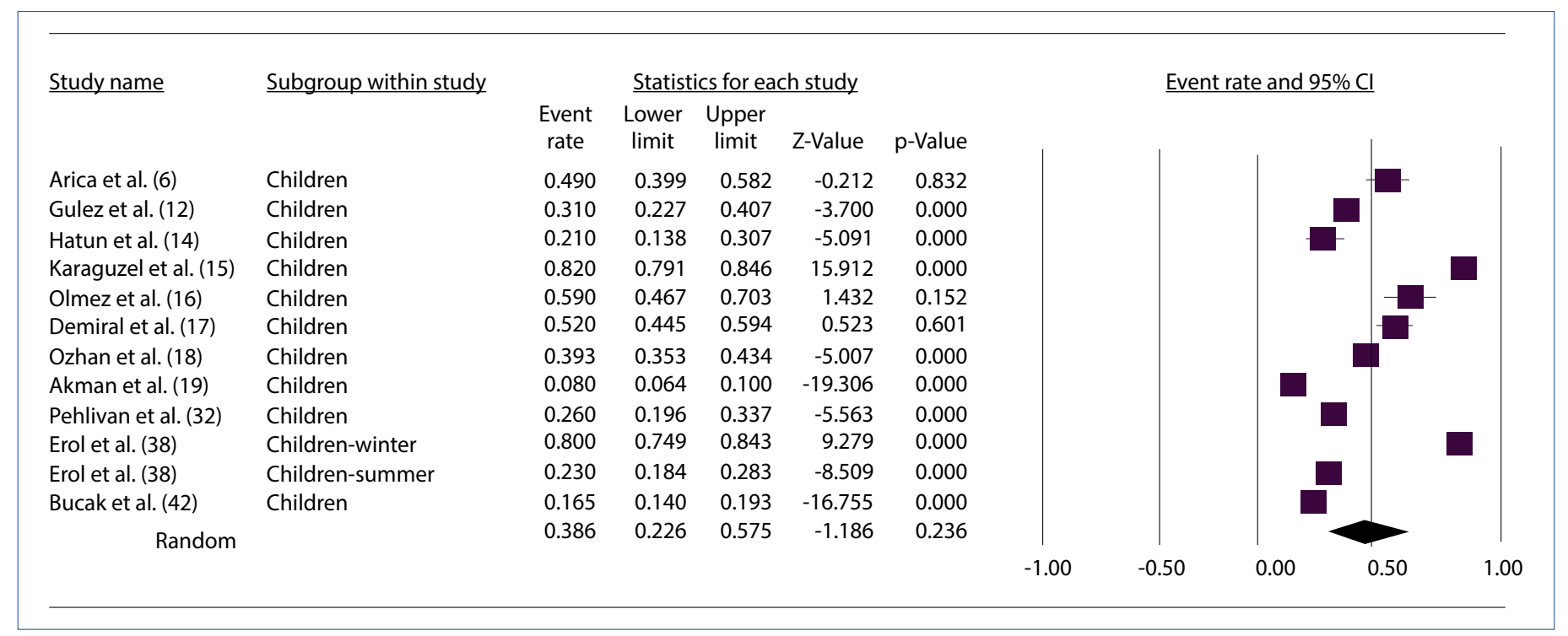

Figure 4. Forest plot of prevalence of vitamin D deficiency in children.

\begin{tabular}{|c|c|c|c|c|c|c|c|c|c|c|c|}
\hline \multirow[t]{2}{*}{$\underline{\text { Study name }}$} & \multirow[t]{2}{*}{$\underline{\text { Subgroup within study }}$} & \multicolumn{5}{|c|}{$\underline{\text { Statistics for each study }}$} & \multicolumn{5}{|c|}{ Event rate and $95 \% \mathrm{Cl}$} \\
\hline & & $\begin{array}{l}\text { Event } \\
\text { rate }\end{array}$ & $\begin{array}{c}\text { Lower } \\
\text { limit }\end{array}$ & $\begin{array}{l}\text { Upper } \\
\text { limit }\end{array}$ & Z-Value & $\mathrm{p}$-Value & & & & & \\
\hline Alpdemir et al. (21) & Female & 0.753 & 0.740 & 0.766 & 31.920 & 0.000 & & & & & \\
\hline Hekimsoy et al. (23) & ) Female & 0.787 & 0.734 & 0.832 & 8.825 & 0.000 & & & & & \\
\hline Kurt et al. (25) & Female & 0.453 & 0.420 & 0.486 & -2.764 & 0.006 & & & & & \\
\hline Ogus et al. (36) & Female & 0.500 & 0.483 & 0.517 & 0.000 & 1.000 & & & & & \\
\hline Durmaz et al. (40) & Female & 0.766 & 0.694 & 0.825 & 6.351 & 0.000 & & & & & \\
\hline Serdar et al. (41) & Female & 0.503 & 0.493 & 0.513 & 0.597 & 0.551 & & & & & \\
\hline Matyar et al. (46) & Female & 0.620 & 0.614 & 0.626 & 37.365 & 0.000 & & & & & \\
\hline Durmus et al. (28) & Female & 0.757 & 0.691 & 0.813 & 6.700 & 0.000 & & & & & \\
\hline \multirow{2}{*}{\multicolumn{2}{|c|}{ Random }} & 0.647 & 0.575 & 0.712 & 3.935 & 0.000 & & & & & \\
\hline & & & & & & & -1.00 & -0.50 & 0.00 & 0.50 & 1.00 \\
\hline
\end{tabular}

Figure 5. Forest plot of prevalence of vitamin D deficiency in female. 


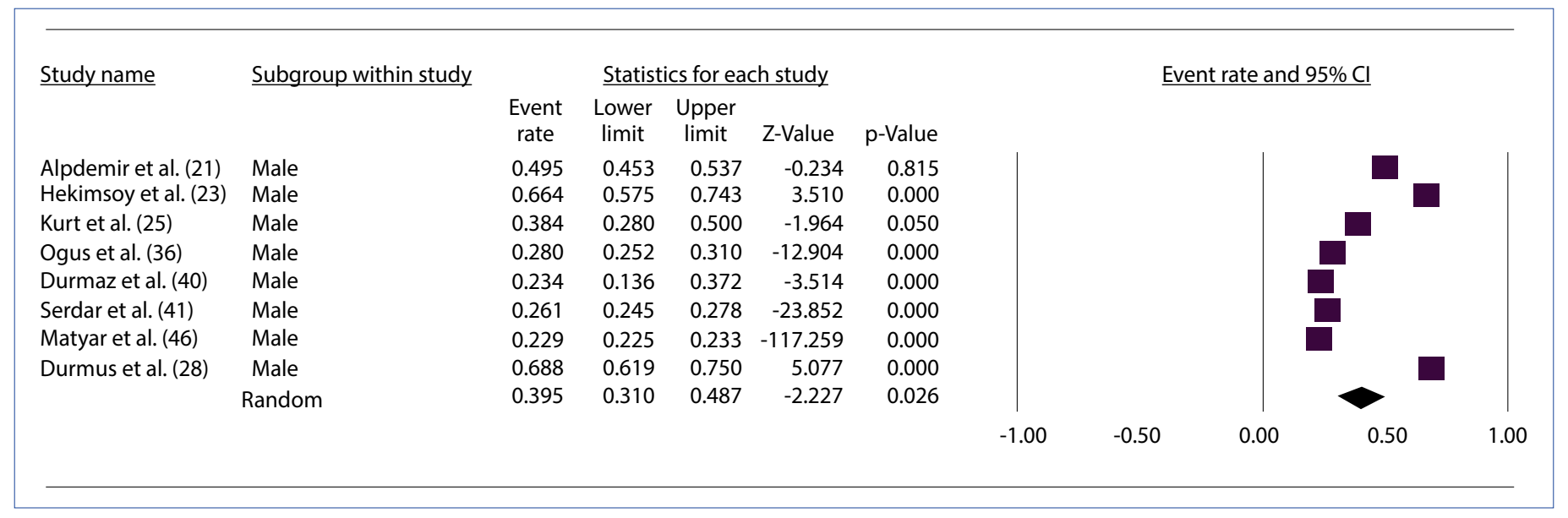

Figure 6. Forest plot of prevalence of vitamin D deficiency in male.

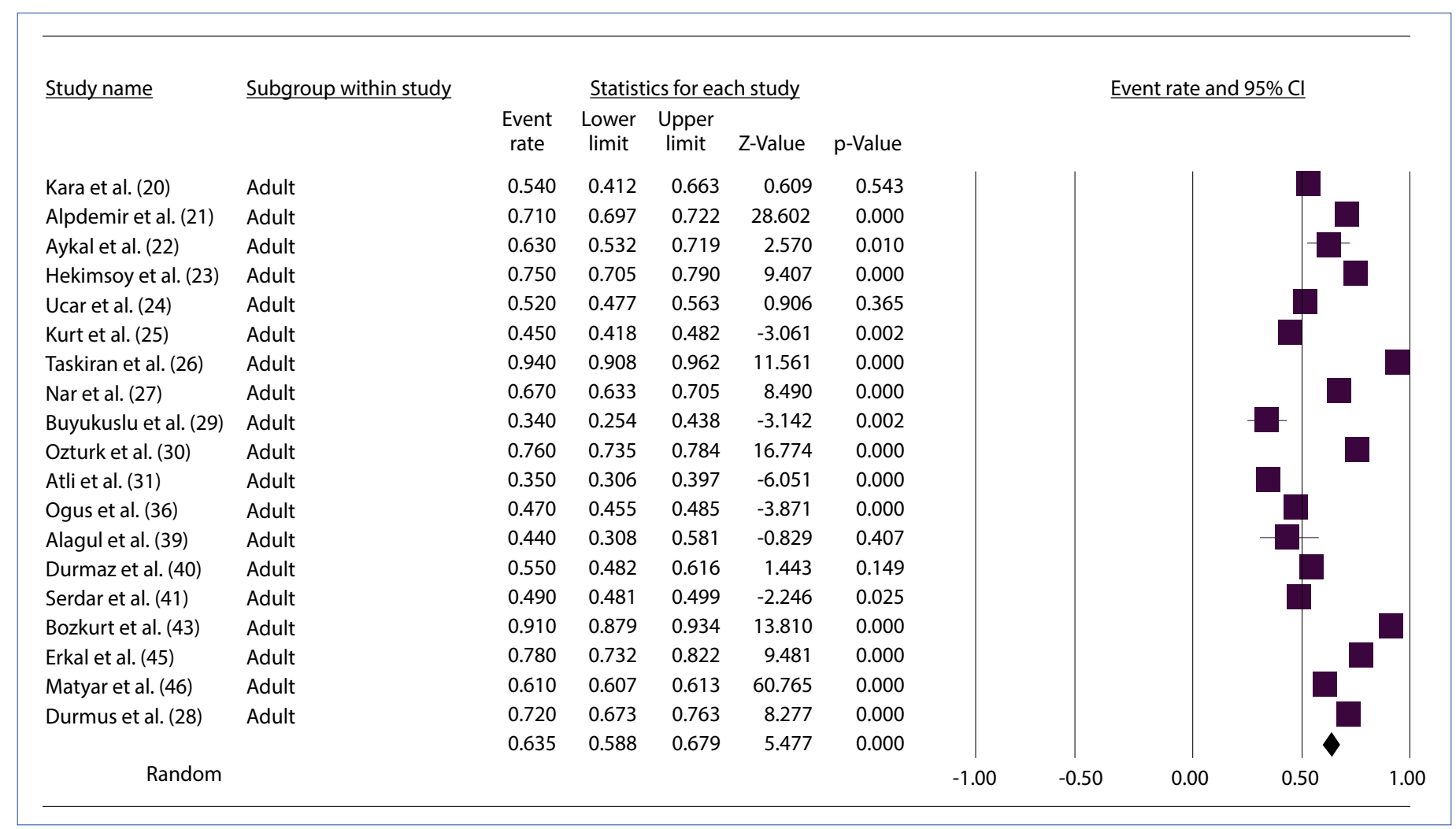

Figure 7. Forest plot of prevalence of vitamin D deficiency in adult.

$21.3 \%$ and inadequacy of vitamin D of $43.8 \%$. Karaguzel et al. [15] found a vitamin D deficiency level of $78 \%$ for males and $87 \%$ for females in the adolescents included in their study performed in Trabzon. This difference according to sex was statistically significant. Olmez et al. [16] determined a vitamin D deficiency of $59.4 \%$ in spring and $25 \%$ in autumn in a study of adolescents in Izmir aged 14-18 years. In the study conducted by Demiral et al. [17], the incidence of vitamin D deficiency was found to be $51.5 \%$ and inadequacy was recorded at a rate of $35.1 \%$ for children in the age group of 3-18 years in the Eskisehir region. Ozhan et al. [18] also found that among
556 children aged between 0-18 years there was a vitamin D deficiency of 39.3\%. Vitamin D deficiency was observed in $13.8 \%$ of infants (0-1 years), $24.6 \%$ of toddlers-preschoolers (1-5 years), 54\% in young school-age children (6-11 years), and $67.7 \%$ of teenagers (12-18 years) [18]. Akman et al. [19] found that there was vitamin D deficiency and inadequacy of $8 \%$ and $25.5 \%$, respectively, in healthy children aged 1-16.

\section{Adults}

Table 3 displays the results obtained from studies of adults. Kara et al. [20] found a vitamin D deficiency of $53.7 \%$ in a study 


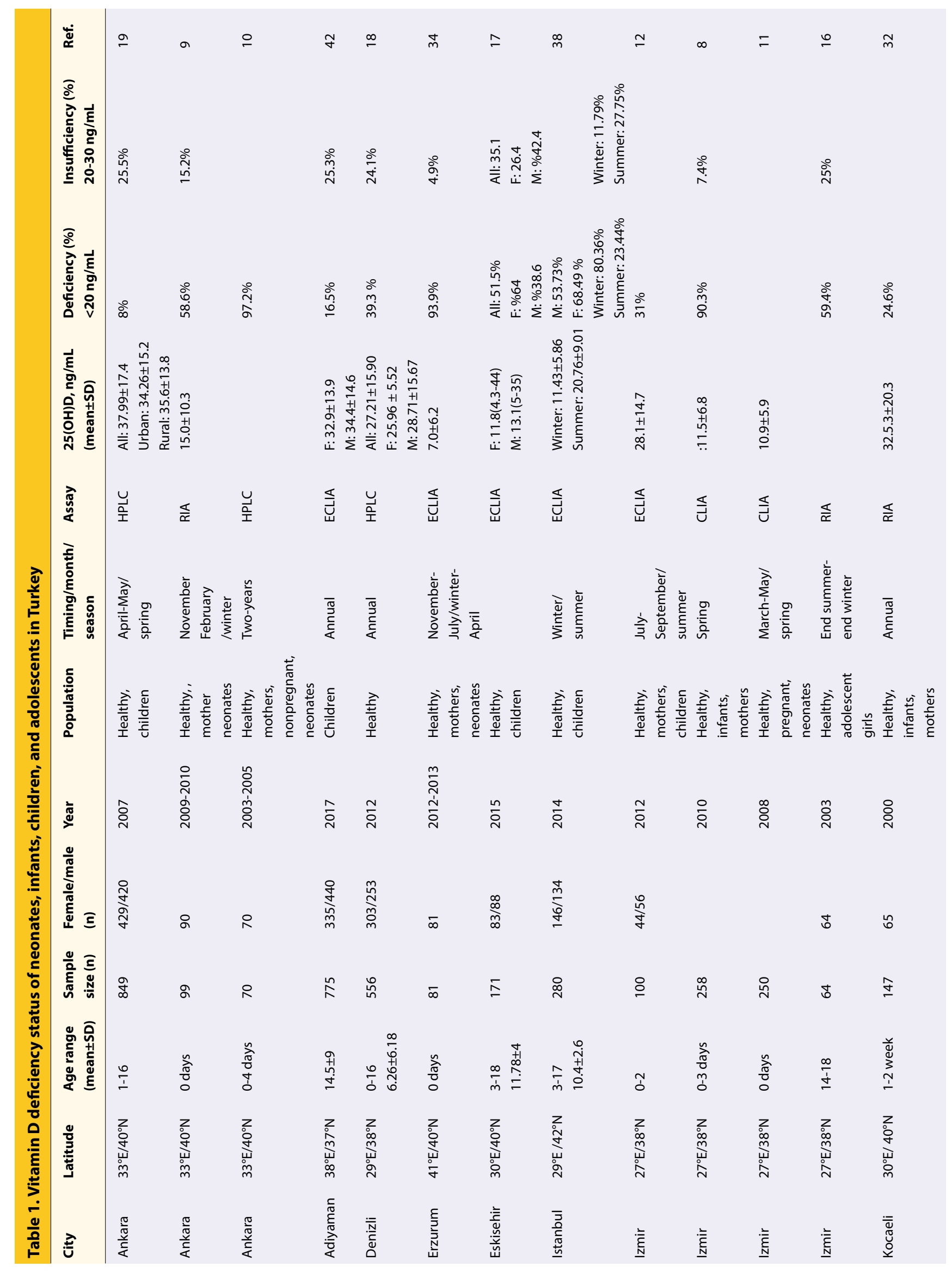




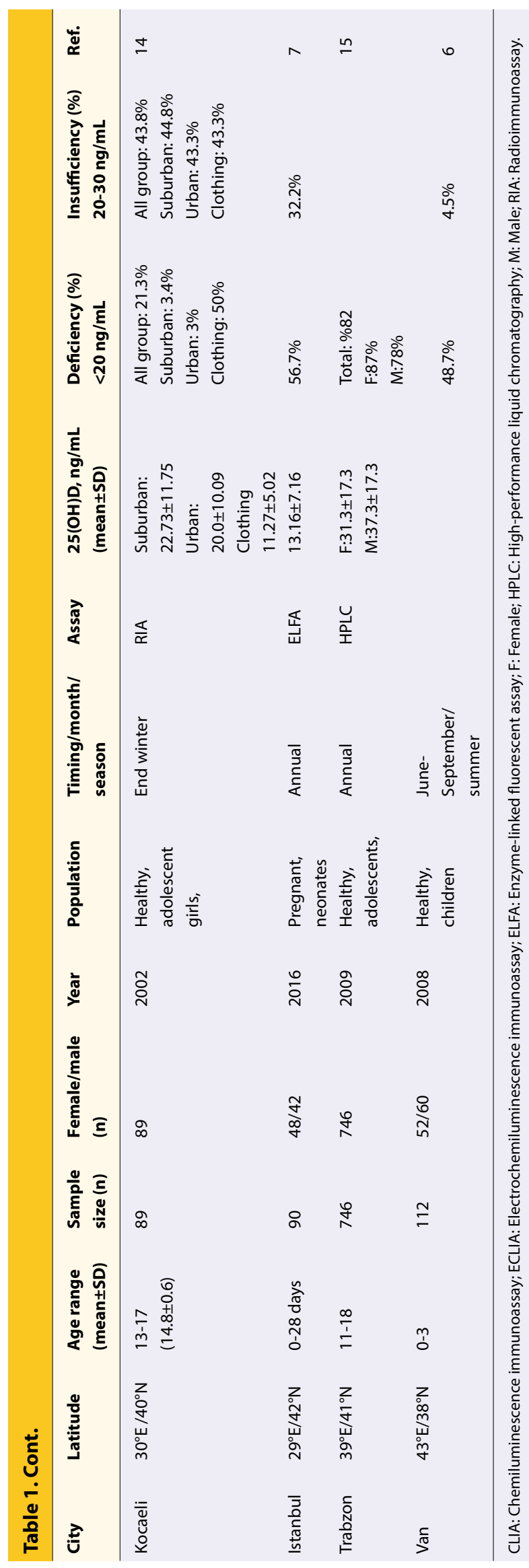

of individuals aged 29-86 years. Alpdemir et al. [21] determined an incidence of vitamin D deficiency of $71 \%$ for individuals in the province of Balikesir aged 18-70 years. In a study conducted in Antalya by Aykal et al. [22], it was determined that there was vitamin $D$ deficiency in $63 \%$ of the patients aged 20 40 years. Hekimsoy et al. [23] found that vitamin D deficiency in the Manisa region was $74.9 \%$. Uçar et al. [24] reported an incidence of vitamin D deficiency of $51.8 \%$ in Ankara adults aged 18-70. There was no significant difference in the vitamin $D$ concentration between age groups in this study. Kurt et al. [25] reported a vitamin D deficiency rate of $44.8 \%$ for individuals aged 23-89 years in Ankara. In another study conducted in Turkey's southeastern province of Diyarbakir, vitamin D deficiency was recorded at 94\% [26]. Nar et al. [27] determined a vitamin $D$ deficiency level of $66.3 \%$ in a study of adult patients in Kırşehir. In a summer study in Kayseri, Durmus et al. [28] determined that vitamin D deficiency was found in $72.1 \%$ of the adult patients studied. Buyukuslu et al. [29] reported that in samples obtained from women aged 18-29 years with a bachelor's degree measured in April and May, 34\% displayed vitamin $D$ deficiency.

\section{Elderly}

The findings of studies analyzing elderly individuals are provided in Table 2. There was no significant difference in the vitamin $D$ level of individuals over 70 years of age compared with other age groups in the study performed by Uçar et al.[24]. Ozturk et al. [30] reported that vitamin D levels in geriatric patients were lower than those of adult patients, but without a statistically significant difference $(p=0.437)$. In a study of individuals over 65 years of age conducted by Atli et al. [31], vitamin $D$ deficiency was determined in $33.4 \%$ of all of the study subjects $(n=420)$. The authors noted vitamin $D$ deficiency in $40.1 \%$ of those living in a retirement home $(54.1 \%$ of females and $18.4 \%$ of males) and in $24.4 \%$ of subjects living in their own home ( $27.9 \%$ of females and $4.2 \%$ of males).

\section{Pregnant women}

In Table 3 the outcomes of studies performed with pregnant women and infants in different regions of the country are shown. In 2003, Pehlivan et al. [32] reported that the vitamin D level of $94.8 \%$ of the mothers and $24.6 \%$ of the infants studied was $<16 \mathrm{ng} / \mathrm{mL}$. In 2008, Halicioglu et al. [8] reported that the vitamin $\mathrm{D}$ concentration in $90.3 \%$ of the pregnant women in a study in Izmir, which has a sunny climate, was $\leq 20 \mathrm{ng} / \mathrm{mL}$. In a 2010 study in Ankara, the incidence of vitamin D deficiency $(\leq 20 \mathrm{ng} / \mathrm{mL}$ ) in pregnant women and their infants was found to be $62.6 \%$ and $58.6 \%$, respectively [10]. In another study performed in Ankara, the rate of vitamin D deficiency in pregnant women was determined to be $35.9 \%$ [33]. In the 


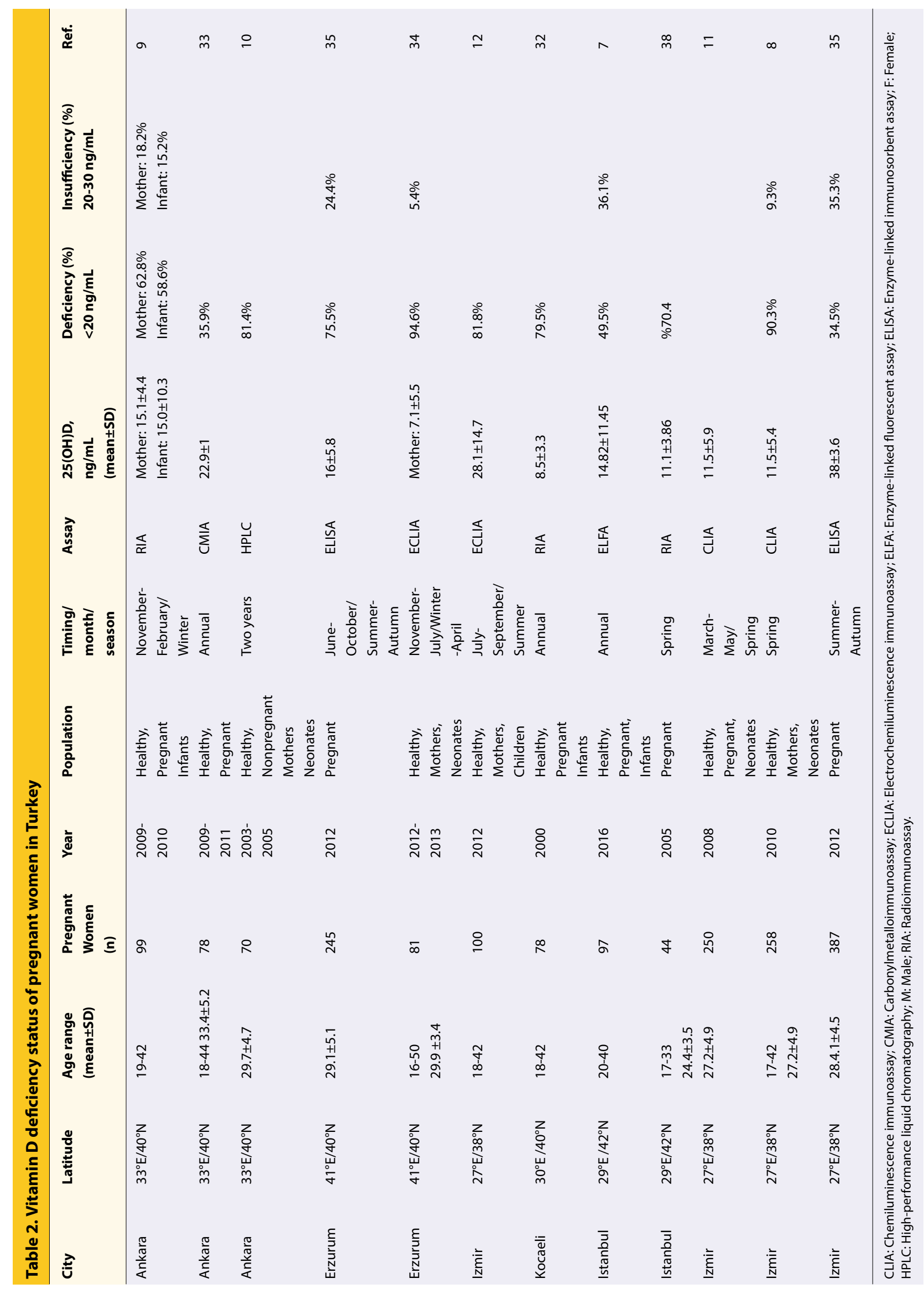




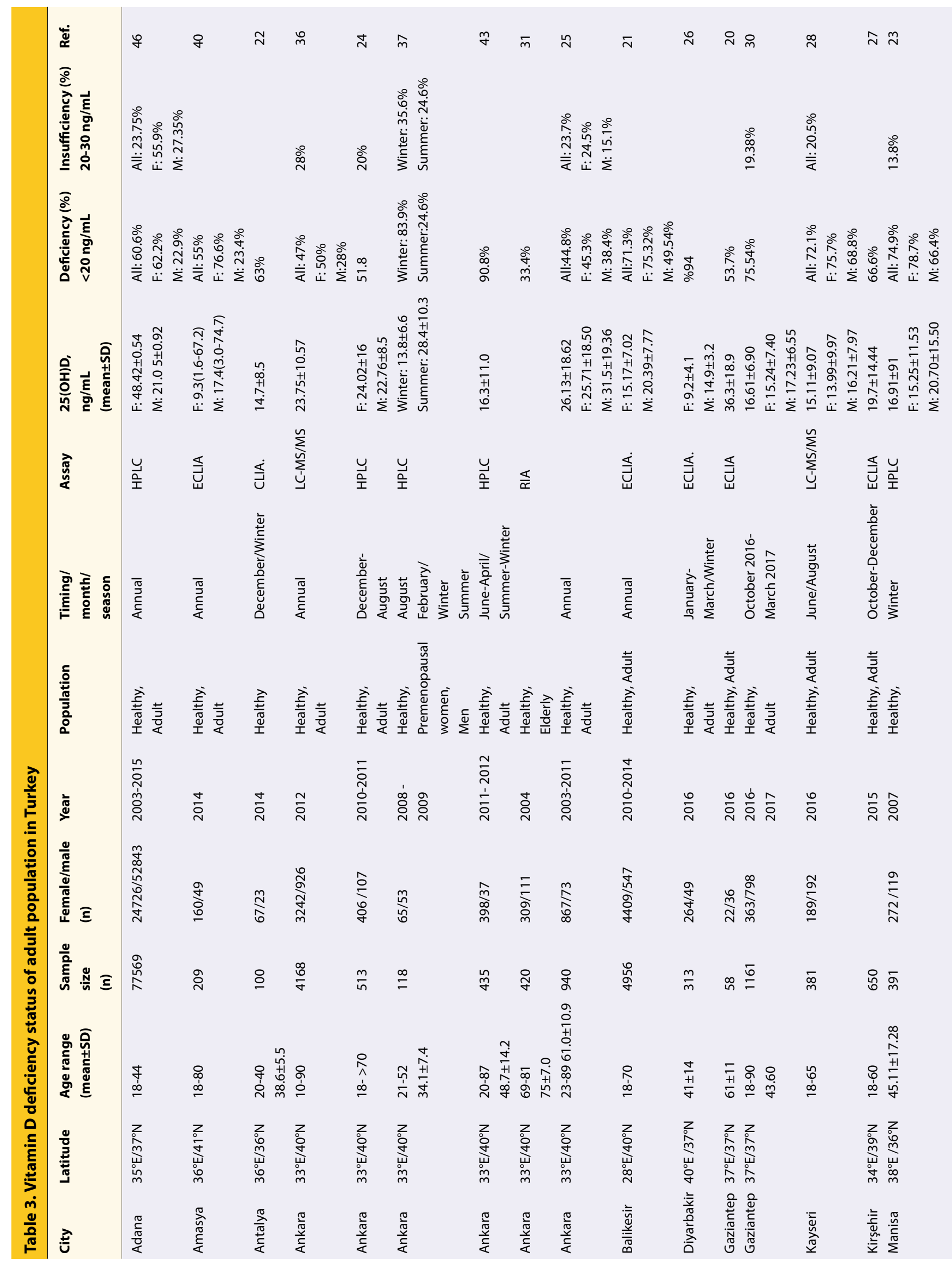




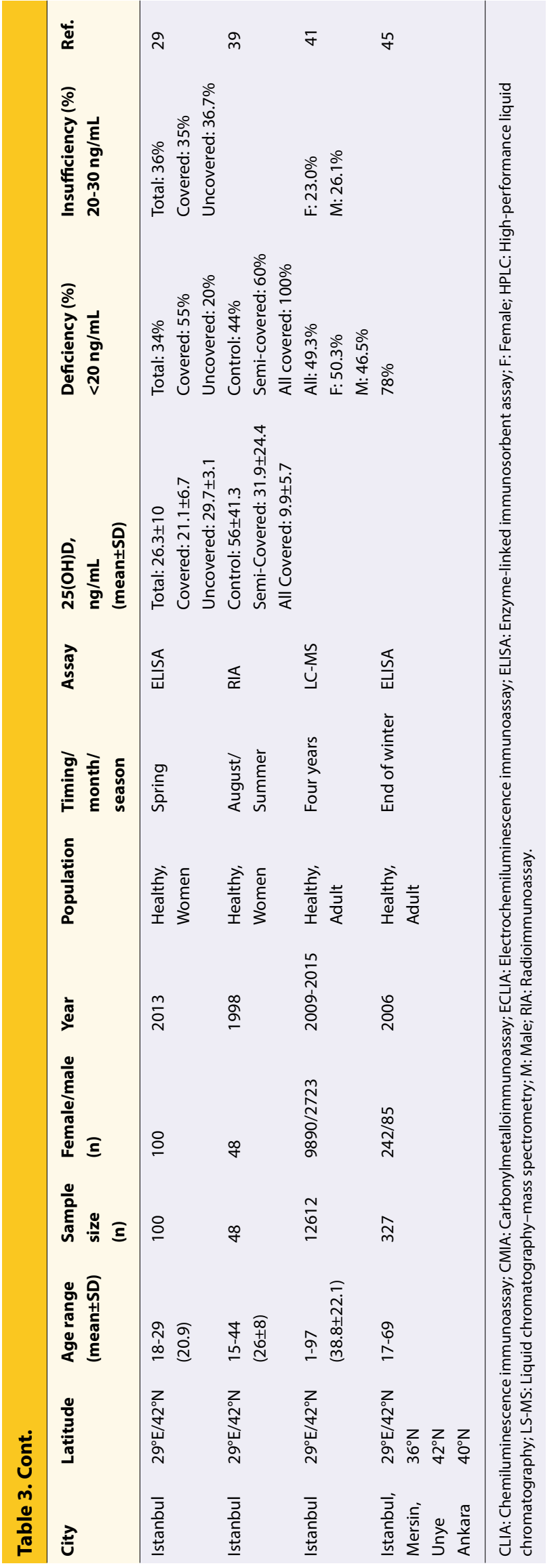

2016 study performed by Ozdemir et al. [7], the mean vitamin D concentration was $14.82 \pm 11.45 \mathrm{ng} / \mathrm{mL}$ in pregnant women and $13.16 \pm 7.16 \mathrm{ng} / \mathrm{mL}$ in their infants. Vitamin D deficiency was present in $49.5 \%$ of mothers and $56.7 \%$ of infants. Alp et al. [34] found that $94.6 \%$ of pregnant women in Erzurum province demonstrated vitamin D deficiency. In 2012, Gur el al. examined vitamin D deficiency in Izmir and Erzurum and reported results of $34.5 \%$ and $75.5 \%$, respectively, in a total of 387 participants [35]. Gur et al. reported that a vitamin D deficiency prevalence among pregnant women in Izmir of $27.8 \%$ and $76.3 \%$ in Erzurum [35].

\section{Effect of age, sex, and season}

Ogus et al. [36] retrospectively determined a rate of vitamin D deficiency in men of $38 \%$ and $50 \%$ in women. In this study, the mean $25(\mathrm{OH}) \mathrm{D} 3$ was $22.49 \pm 13.88 \mathrm{ng} / \mathrm{mL}$ in women and $23.75 \pm 10.57 \mathrm{ng} / \mathrm{mL}$ in men. The patients were aged $10-90$ years and it was noted that the $25(\mathrm{OH}) \mathrm{D} 3$ concentration measured in April was greater than that of October. In addition, the 25(OH) D3 concentration was higher in young people and lower in older adults ( $>70$ years). Cinar et al. [37] also observed a significant difference in assessments according to season: The rate of vitamin D deficiency was $24.6 \%$ in summer and $83.9 \%$ in winter. Karaguzel et al. [15] reported that among adolescents in Trabzon, the vitamin D deficiency level recorded was $71 \%$ in the autumn and $92 \%$ in the spring. This difference was statistically significant. In a study in Istanbul, a city with a sunny climate, Erol et al. [38] found that the mean serum 25(OH)D3 levels at the end of winter were significantly lower compared with end of summer levels. Vitamin D deficiency was recorded among adolescents in this study in $53.3 \%$ of females and $68.49 \%$ of males. In 1998, Alagol et al. [39] found that vitamin D levels were low in $66.6 \%$ of women of reproductive age in Istanbul. Ozhan et al. [18] found that the rate of vitamin D deficiency was $45.1 \%$ for females and $32.4 \%$ for males in 556 children aged $0-18$ years. The overall prevalence of vitamin D deficiency in this study was $33.3 \%$ in spring, $15.5 \%$ in summer, $55.5 \%$ in autumn, and $44.9 \%$ in winter. Durmaz et al. [40] observed a significant difference in vitamin $D$ levels between women and men. They reported vitamin D deficiency in $76.6 \%$ of women and $17.4 \%$ of men. There was no significant difference observed between age groups in that study. Hekimsoy et al. [23] found a vitamin D deficiency rate of $75.5 \%$ among women and $66.4 \%$ among men in their study of Manisa residents. There was no significant difference in 25(OH)D3 level according to age group. In a study performed in the Balikesir region, Alpdemir and Alpdemir [21] measured a rate of vitamin D deficiency of $75.32 \%$ for women and $49.54 \%$ for men. The authors reported results of $84.84 \%$ in winter, $81.27 \%$ in spring, $63.63 \%$ in summer, and $59.06 \%$ in autumn. There was no statistically significant difference between groups 
when examined by age group. In a study of seasonal changes in 25(OH)D3 values from 2009-2015 conducted by Serdar et al. [41], the findings indicated an increase starting in June, reaching a high concentration in September, and then decreasing by December. There was no statistical difference in $25(\mathrm{OH}) \mathrm{D} 3$ levels between men and women, while there were statistically significant differences between seasons. In their study, a variation in vitamin $D$ according to age was observed. An increased level of vitamin $D$ was seen in the first decade, which may have been due to vitamin $D$ supplemention in this period. There was a significant reduction in vitamin $\mathrm{D}$ concentration between the ages $10-40$ years. In other age groups (40-90 years), the mean value of vitamin $D$ demonstrated an increase with age. Cinar et al. [37] did not observe any significant difference in the level of vitamin $D$ between men and women. There was no significant difference in vitamin $D$ measurements between seasons in a study of children performed by Buçak et al. [42]. There was no significant difference observed according to age groups or sex (aged 18-70 years) in research done by Uçar et al. [24] in Ankara. Bozkurt et al. [43] reported that a large percentage of the adult Turkish population had an insufficient level of vitamin $D$ during the winter and summer. While they found that serum vitamin D concentrations were significantly lower in the winter compared with the summer season, the deficiency of vitamin D was $94 \%$ in the winter and $85 \%$ in the summer. There were no differences in vitamin $D$ concentration with respect to age or sex [43].

The available data on vitamin D status vary regarding sex and age. In general, the prevalence of vitamin D deficiency is higher in women. In addition, vitamin D levels did not change in the adult age group in the majority of studies. However, there was a different prevalence of vitamin $D$ deficiency when analyzed according to the season.

\section{Clothing style}

The effect of clothing on vitamin D levels is demonstrated in Tables 1, 2 and 3. In Istanbul, Alagol et al. [39] studied 3 groups classified by the style of dress. The first group (Group I), the control group, consisted of 18 women who dressed in a style that exposed the usual areas of the skin to sunlight. In the second group (Group II), 15 women covered their whole body, excluding the hands and face, and 15 women in the third group (Group III) covered their whole body, including the hands and face with a veil and gloves due to religious belief. The mean serum vitamin $D$ concentration in the summer season was $56 \pm 41.3 \mathrm{ng} / \mathrm{mL}$ in Group I, 31.9 $\pm 24.4 \mathrm{ng} / \mathrm{mL}$ in Group Il, and $9.9 \pm 5.7 \mathrm{ng} / \mathrm{mL}$ in Group III. In another study conducted among pregnant women in Izmir, the mean vitamin D concentration was $24.5 \mathrm{ng} / \mathrm{mL}$ in covered women and $31.6 \mathrm{ng} / \mathrm{mL}$ in uncovered women. The mean vitamin $D$ concentration was $15 \mathrm{ng} / \mathrm{mL}$ in covered preg- nant women and $17.9 \mathrm{ng} / \mathrm{mL}$ in uncovered pregnant women in Erzurum [35]. In another study of pregnant women, Halicioglu et al. [8] found a significant difference between covered and uncovered styles of dress among women. Erol et al. [38] observed a deficiency of vitamin D in $70 \%$ of 44 pregnant women who observed a covered dressing style. Hatun et al. [14] identified vitamin D deficiency in 3\% of girls who did not wear a headscarf and 50\% in those who did. Similarly, Pelivan et al. [32] reported that pregnant women who wore an abaya had lower levels of vitamins D. In another study conducted in Adana, there was a significant difference in the concentration of vitamin $D$ between women who observed covered and uncovered styles of dress (mean: $33.1 \pm 16 \mathrm{ng} / \mathrm{mL}$ and $53.9 \pm 27.3 \mathrm{ng} / \mathrm{mL}$, respectively) [44]. Buyukuslu et al. [29] observed vitamin D deficiency in $55.0 \%$ of covered students and $20.0 \%$ of uncovered students. The vitamin D status was statistically significant and there was a negative correlation with the age at which young women adopt an Islamic style of dress $(p<0.05 ; r=-0.334)$.

\section{Regional difference}

Vitamin D levels according to region are displayed in Tables 1,2 and 3. Gur et al. [35], compared the $25(\mathrm{OH}) \mathrm{D} 3$ concentrations of pregnant women living in 2 provinces located in the eastern and western regions of Turkey. Izmir and Erzurum are very distinct provinces with respect to both geographical and climatic conditions and social life: Izmir (latitude $27^{\circ}$ ) has an elevation of $2 \mathrm{~m}$ above sea level, while Erzurum (latitude $41.1^{\circ}$ ) has an elevation of $1893 \mathrm{~m}$. The mean 25(OH)D3 concentration was $38 \pm 3.5 \mathrm{ng} / \mathrm{mL}$ in Izmir and $16 \pm 5.8 \mathrm{ng} / \mathrm{mL}$ in Erzurum. The prevalence of vitamin D deficiency reported was $27.8 \%$ in Izmir and $76.3 \%$ in Erzurum in the study performed by Gur et al. [35]. Karaguzel et al. [15] determined that the deficiency of vitamin D in Trabzon (latitude $41^{\circ}$ ) was $93 \%$ at the end of winter and $7 \%$ at the end of summer [15]. In their study conducted in the Izmir region, Olmez et al. [16] recorded a deficiency of vitamin D of $59.4 \%$ at the end of winter and $25 \%$ at the end of summer. Erkal et al. [45] found that the median 25(OH)D3 concentration in Turks from Mersin $\left(37^{\circ} \mathrm{N}\right.$, a southern Turkish city) was statistically significantly higher than values assessed in cities further north, such as Istanbul, Ankara and the town of Unye $\left(40-41^{\circ} \mathrm{N}\right.$ ) (females: $p=0.0018$; males: $\left.p=0.0015\right)$. Matyar et al. [46] observed that vitamin $D$ deficiency and insufficiency was $60.6 \%$ and $23.78 \%$, respectively, among residents of the Cukurova area (a southern region) aged 18-44 years.

\section{Discussion}

In this study, we reviewed the literature and identified 40 original studies related to vitamin D concentration in Turkey. We conducted a screening study considering age, gender, pregnancy, clothing style, region, and season in terms of vitamin 
D concentrations. The prevalence of vitamin D deficiency observed varied from $24 \%$ to $99 \%$ in various studies and regions. The pooled prevalence rate of vitamin D deficiency was $63 \%$ for the overall population in our meta-analysis review. Therefore, vitamin $D$ deficiency continues to be a severe problem throughout Turkey. Vitamin D serum concentrations may be affected by gender, age, pregnancy, season, and cultural differences.

Vitamin $D$ deficiency is a widespread condition that is said to affect about 1 billion people worldwide [4]. A previous review of vitamin $D$ deficiency in Turkey revealed a wide rate of severe deficiency of $8 \%$ to $84 \%$ [47]. Over the past 2 decades, several national population-based epidemiological studies in the United States, Canada, the United Kingdom, and New Zealand have reported a deficiency rate of $18 \%$ to $36 \%$. It was reported that the vitamin $D$ deficiency rate among the Australian population was $39 \%$ for women and $22 \%$ for men [48].

The prevalence rate of vitamin $\mathrm{D}$ deficiency was determined to be $86.6 \%$ for neonates and $76 \%$ for mothers in this metaanalysis. As seen in our study, vitamin D deficiency is still a serious health problem, especially in pregnant women, neonates, and infants among those of low socio-economic status in the Turkish population. A vitamin D supplement program was initiated to provide vitamin D supplementation of 400 IU D per day for all infants from birth to 1 year of age, and for all pregnant women at dose of $1200 \mathrm{IU} /$ day starting from 12 weeks of pregnancy [9]. Nonetheless, all of these data confirm that vitamin $\mathrm{D}$ deficiency continues to be a problem in pregnant women in Turkey and their infants. It has been reported that the level of vitamin $D$ in pregnant women can be affected by factors such as geographical region, sunbathing habits, style of dress, body mass index, the educational level of the mother, socioeconomic status, dairy product consumption, and external vitamin D supplementation [6-12]. It was observed in this meta-analyses study that rate of vitamin $D$ deficiency varied from $57 \%$ to $93 \%$ for infants and from $62 \%$ to $95 \%$ for pregnant women. In studies conducted in other countries, the prevalence of vitamin D deficiency was $3 \%$ to $86 \%$ for pregnant women and $4 \%$ to $60 \%$ for infants $[42,49]$.

In this meta-analysis, the prevalence rate of vitamin $D$ deficiency ranged between $8 \%$ and $80 \%$. The growth period of childhood and adolescence are the most critical time intervals for skeletal development and are closely related to the levels of calcium and vitamin D absorbed. Vitamin D deficiency is common in this period. As was evident in this review, it is also important to consider the season and province [14-20].

The results of this meta-analysis suggest that the serum $25(\mathrm{OH})$ D3 concentration level may be associated with gender and season. Biological differences, behavioral differences, and style of dress (e.g., wearing a veil) are often mentioned as reasons for a higher prevalence of vitamin $D$ deficiency among women than men. As seen in studies performed in Turkey and other countries, vitamin $D$ deficiency is significantly common in women $[18,21,23,38-41]$. A lower serum $25(\mathrm{OH}) \mathrm{D} 3$ concentration among older participants may partly be the result of the lower capacity of the skin to produce vitamin D after exposure to sunlight, reduced activity and immobility among the elderly, and insufficient sunshine exposure $[31,50]$. There is an apparent change in the level of vitamin $D$ according to the season. According to many studies, the incidence of vitamin D deficiency increases in autumn and winter, and decreases in summer and spring $[15,18,21,41,35-37,38,43]$. A negative correlation between age and vitamin $D$ concentrations has been reported in many studies, though in some research, vitamin D concentration did not change with age in adults [21, 23, 39, 41-43].

Studies conducted to compare regional differences in vitamin $D$ levels have revealed that the prevalence of vitamin $D$ deficiency was lower in cities at a lower latitude. Populations living at southern latitudes are exposed to more sunlight, which contributes to the serum vitamin D level $[7,15,45]$.

Traditional and regional clothing styles and Islamic beliefs that promote a more covered style of dress for women are common in Turkey. Clothing is a factor that affects the level of vitamin $D$ absorption because it prevents exposure to direct sunlight. Our analysis showed that vitamin D status was affected by a covered style of dress and had a negative correlation with the duration of the observation of a covered style of dress $[8,16,27,31,37,38]$.

There are some limitations that should be considered. The prevalence of vitamin $D$ deficiency was not mentioned directly in all of the studies used in this analysis; the prevalence rate for some studies was calculated by the authors based on the data available from the study. Different methods (RIA, enzymelinked immunosorbent assay, electrochemical luminescence immunoassay, electron ionization, HPLC, and LC-MS/MS) were used to measure vitamin D concentrations. Therefore, the results should be evaluated carefully.

\section{Conclusion}

In light of the results obtained in this meta-analysis, there is a clear vitamin D deficiency in Turkey, which varies from $58.9 \%$ to $66.6 \%$ in studies with a $95 \% \mathrm{Cl}$. Gender, age, season, location, exposure to sunlight, clothing, socioeconomic status, and religious beliefs affect the vitamin $D$ level in the body.

To our knowledge, this study is the first meta-analysis to describe the current national status of vitamin D levels in Turkey. Vitamin D deficiency or insufficiency continues to be a significant public health issue in Turkey. Neonates, pregnant women, women, and the elderly in particular have a higher risk of vitamin deficiency. Our results support a recommendation that the level of vitamin $D$ in the Turkish population should be periodically measured and if necessary, appropriate supplements should be taken to prevent a secondary chronic disease due to deficiency of vitamin D.

\section{Conflict of interest: None declared.}

Financial Disclosure: None declared. 
Peer-review: Externally peer-reviewed.

Authorship contributions: Concept - M.A.; Design - M.A.; Supervision - M.F.A.; Data collection \&/or processing - M.A., M.F.A.; Analysis and/or interpretation - M.A., M.F.A.; Literature search M.A., M.F.A.; Writing - M.A.; Critical review - M.A., M.F.A.

\section{References}

1. Holick MF.Vitamin D status: measurement, interpretation, and clinical application. Ann Epidemiol 2009;19:73-8. [CrossRef]

2. Holick MF, Binkley NC, Bischoff-Ferrari HA, Gordon CM, Hanley DA, Heaney RP, et al. Evaluation, treatment, and prevention of vitamin D deficiency: an Endocrine Society clinical practice guideline. J Clin Endocrinol Metab 2011;96:1911-30. [CrossRef]

3. Souberbielle JC, Body JJ, Lappe JM, Plebani M, Shoenfeld Y, Wang TJ, et al. Vitamin D and musculoskeletal health, cardiovascular disease, autoimmunity and cancer: Recommendations for clinical practice. Autoimmun Rev 2010;9:709-15.

4. Arabî A, El Rassi R, El-Hajj Fuleihan G. Hypovitaminosis D in developing countries-prevalence, risk factors and utcomes. Nat Rev Endocrinol 2010;6:550-61. [CrossRef]

5. Holick MF, Chen TC. Vitamin D deficiency: a worldwide problem with health consequences. Am J Clin Nutr 2008;87:1080-6.

6. Arıca V, Gucuk S, Edirne T. Levels of serum 25-OHD in healthy children age 0-36 months in Van. Turk Arch Ped 2010;45:28690. [CrossRef]

7. Ozdemir AA, Ercan Gundemir Y, Kucuk M, Yildiran Sarica D, Elgormus Y, Cag Y, et al. Vitamin D Deficiency in Pregnant Women and Their Infants. J Clin Res Pediatr Endocrinol 2018;10:44-50. [CrossRef]

8. Halicioglu O, Aksit S, Koc F, Akman SA, Albudak E, Yaprak I, et al. Vitamin $D$ deficiency in pregnant women and their neonates in spring time in western Turkey. Paediatr Perinat Epidemiol 2012;26:53-60. [CrossRef]

9. Gur G, Abaci A, Koksoy AY, Anik A, Catli G, Kislal FM, et al. Incidence of maternal vitamin $D$ deficiency in a region of Ankara, Turkey: a preliminary study. Turk J Med Sci 2014;44:616-23.

10. Ergur AT, Berberoglu M, Atasay B, Siklar Z, Bilir P, Arsan S, et al. Vitamin $D$ deficiency in Turkish mothers and their neonates and in women of reproductive age. J Clin Res Pediatr Endocrinol 2009;1:266-9. [CrossRef]

11. Yildiz O, Colak A, Coker I, Turkon H. Vitamin D correlation between mother and baby during pregnancy in the winter. Turk J Biochem 2012;37:145-9. [CrossRef]

12. Gulez P, Korkmaz HA, Ozkok D, Can D, Ozkan B. Factors Influencing Serum Vitamin D Concentration in Turkish Children Residing in İzmir: A Single-Center Experience. J Clin Res Pediatr Endocrinol 2015;7:294-300. [CrossRef]

13. Kara Elitok G, Bulbul L, Zubarioglu U, Kıray Bas E, Acar D, Uslu $S$, et al. How should we give vitamin D supplementation? evaluation of the pediatricians' knowledge in Turkey. Ital J Pediatr 2017;43:95. [CrossRef]

14. Hatun S, Islam O, Cizmecioglu F, Kara B, Babaoglu K, et al. Subclinical vitamin $D$ deficiency is increased in adolescent girls who wear concealing clothing. J Nutr 2005;135:218-22. [CrossRef]
15. Karaguzel, Dilber B, Can G, Okten A, Deger O, Holich MF. Seasonal Vitamin D Status of Healthy shoolchildren and Predictors of Low Vitamin D Status. J Pediatr Gastroenterol Nutr 2014;58:654-60. [CrossRef]

16. Olmez D, Bober E, Buyukgebi A, Cimrin D. The frequency of vitamin $D$ insufficiency in healthy female adolescents. Acta Pediatr 2006;95:1266-69. [CrossRef]

17. Demiral M, Sırmagul B, Kirel B. Vitamin D levels in children admitted to the endocrine outpatient clinic. J curr Pediatry 2016;14:60-6. [CrossRef]

18. Ozhan B, Evrengul H, Yılmaz AS, Yaşar SU, Demir S. Vitamin D status of children in a university hospital in west turkey. HK J Pediatry 2016;21:251-56.

19. Akman AO, Tumer L, Hasanoğlu A, Ilhan M, Caycı B. The frequency of vitamin $D$ insufficiency in healthy children between 1 and 16 years of age in Turkey. Pediatr Int 2011;53:968-73.

20. Kara N, Ceri S. Vitamin D level in patients with pterygium. Arg bras Oftalmol 2017;80:229-33. [CrossRef]

21. Alpdemir M, Alpdemir MF. Determination of reference range with the indirect method of the 25-hydroxyvitaminD3 test in the Balıkesir region, Turkey. Turk J Med Sci 2016:17;46:151217. [CrossRef]

22. Aykal G, Cerit N. Tekeli SO, Ellidag HY, Yılmaz N. Prevelence of vitamin $D$ insufficiency and deficiency in operatin room personel. [Article in Turkish]. Turk Klinik Biyokimya derg 2016;14:18-25.

23. Hekimsoy Z, Dinc G, Kafesciler S, Onur E, Guvenc Y, Pala T, et al. Vitamin $D$ status among adults in the Aegean region of Turkey. BMC Public Health 2010;10:782. [CrossRef]

24. Ucar F, Taslipinar MY, Soydas AO, Ozcan N. 25-OH vitamin D levels in patients admited to Ankara Etlik Ihtisas Training and Research Hospital. Eur J Basic Med Sci 2012;2:12-5.

25. Kurt M, Comertoglu I, Sarp U, Yalcin P, Dincer G. Vitamin D levels in patients with osteoporosis. Turkish Journal of Osteoporosis 2011;17:68-70.

26. Taskiran B, Cansu GB. Vitamin D deficiency in adult residents of southern Turkey. [Article in Turkish]. Osmangazi Journal of Medicine 2017:39:13-20.

27. Nar R. Emekli ID, Güçlü K. Hba1c ile vitamin D düzeyleri arasındaki ilişkinin değerlendirilmesi [Abstract]. Turk Klinik Biyokimya Derg 2016;14:Special Issue:P-11.

28. Durmus H, Cetinkaya F. Vitamın D status of adults in Kayseri, Turkey: Summer time population based cross-sectional study. J Clin Anal Med 2017;8: 325-9. [CrossRef]

29. Buyukuslu N, Esin K, Hizli H, Sunal N, Yigit P, Garipagaoglu M2. Clothing preference affects vitamin $D$ status of young women. Nutr Res 2014;34:688-93. [CrossRef]

30. Ozturk ZA, Gol M, Turkbeyler İH. Prevalence of vitamin D deficiency in otherwise healthy individuals between the ages of 18 and 90 years in southeast Turkey. Wien Klin Wochenschr 2017;129:854-5. [CrossRef]

31. Atli T, Gullu S, Uysal AR, Erdogan G. The prevalence of vitamin $D$ deficiency and effects of ultraviolet light on vitamin D levels in elderly Turkish population. Arch Gerontol Geriatr 2005;40:53-60. [CrossRef] 
32. Pehlivan I, Hatun S, Aydogan M, Babaoglu K, Gokalp AS. Maternal vitamin $D$ deficiency and vitamin $D$ supplementation in healthy infants. Turk J Pediatr 2003;45:315-20.

33. Parildar H, Dogruk Unal A, Aksan Desteli G, Cigerli O, Guvener Demirag N. Frequency of Vitamin D deficiency in pregnant diabetics at Baskent University Hospital, Istanbul. Pak J Med Sc. 2013;29:15-20. [CrossRef]

34. Alp H, Tekgunduz KS, Akkar MK. Maternal and cord blood vitamin D status in high-altitude pregnancy. J Matern Fetal Neonatal Med 2016;29:571-5. [CrossRef]

35. Gur EB, Turan GA, Tatar S, Gokduman A, Karadeniz M, Celik G, et al. The effect of place of residence and lifestyle on vitamin $D$ deficiency in pregnancy: Comparison of eastern and western parts of Turkey. J Turk Ger Gynecol Assoc 2014;15:149-55.

36. Ogus E, Surer H, Kilinc A, Fidanci V, Yilmaz G, et al. Evaluation of vitamin $D$ levels by months, sex and age. [Article in Turkish]. Ankara Med J 2015;15:1-5. [CrossRef]

37. Cinar N, Harmanci A, Yildiz BO, Bayraktar M. Vitamin D status and seasonal changes in plasma concentrations of 25-hydroxyvitamin D in office workers in Ankara, Turkey. Eur J Intern Med 2014;25:197-201. [CrossRef]

38. Erol M, Yigit O, Kucuk SH, Gayret B. Vitamin D deficiency in children and Adolescents in Bağcılar, Istanbul. J Clin Res Pediatr Endocrinol 2015;7:134-9. [CrossRef]

39. Alagol F, Shihadeh Y, Boztepe H, Azizlerli H, Sandalci O. Sunlight exposure and vitamin D deficiency in Turkish women. J Endocrinol Invest 2000;23:173-7. [CrossRef]

40. Durmaz ZH, Demir AD, Tiryaki M, Delibaş N. Vitamine D levels of individulas in Amasya region. Bozok med J 2015;5:26-32.

41. Serdar MA, Can BB, Kilercik M, Zeynep A. Durer ZA, Aksungar $\mathrm{FB}$, et al. Analysıs of changes in parathyroid hormone and 25 $(\mathrm{OH})$ vitamin $D$ levels with respect to age, gender and season: A Data Mining Study. J Med Biochem 2017;36:73-83. [CrossRef]
42. Bucak IH, Almis H. The retrospective Analysis of vitamin D levels of Pediatric patients in a small city center in Turkey. Sakarya med J 2016; 6:136-40. [CrossRef]

43. Bozkurt S, Alkan BM, Yildiz F, Gumus S, Sezer N, Ardicoglu O, et al. Age, sex, and seasonal variations in the serum vitamin D3 Levels in a local Turkish population. Arch Rheumatol 2014;29:14-9.

44. Guzel R, Kozanoglu E, Guler-Uysal F, Soyupak S, Sarpel T. Vitamin $D$ status and bone mineral density of veiled and unveiled Turkish women. J Womens Health Gend Based Med 2001;10:765-70. [CrossRef]

45. Erkal MZ, Wilde J, Bilgin Y, Akinci A, Demir E, Bodeker RH, et al. High prevalence of vitamin $D$ deficiency, secondary hyperparathyroidism and generalized bone pain in Turkish immigrants in Germany: identification of risk factors. Osteoporos Int 2006;17:1133-40. [CrossRef]

46. Matyar S, Disel NR, Acikalin Akpinar A, Kutnu M, İnaL T. Vitamin $D$ levels in Çukurova Region. [Article in Turkish]. Cukurova Med J 2017;42:320-8. [CrossRef]

47. Van der Meer IM, Middelkoop BJC, Boeke AJP, Lips P. Prevalence of vitamin D deficiency among Turkish, Moroccan, Indian and sub-Sahara African populations in Europe and their countries of origin: an overview. Osteoporos Int 2011;22:1009-21. [CrossRef]

48. Daly RM, Gagnon C, Lu ZX, Magliano DJ, Dunstan DW, Sikaris $K A$, et al. Prevalence of vitamin $D$ deficiency and its determinants in Australian adults aged 25 years and older: a national, population-based study. Clin Endocrinol (Oxf) 2012;77:26-35.

49. Hatun S, Ozkan B, Bereket A. Vitamin D deficiency and prevention:Turkish experience. Acta paediatr 2011;100:1195-9. [CrossRef]

50. Manicourt DH, Devogelaer JP. Urban tropospheric ozone increases the prevalence of vitamin D deficiency among Belgian postmenopausal women with outdoor activities during summer. J Clin Endocrinol Metab 2008;93:3893-9. [CrossRef] 